\title{
Sex Ratio of Ribbonfish, Lepturacanthus Savala (Cuvier, 1829) From Karwar Waters, Karnataka
}

\author{
Sangita R. Kudale/Jadhav ${ }^{1}$ and J. L. Rathod ${ }^{2} *$ \\ ${ }^{\prime}$ (Department of Zoology, Nowrosjee Wadia College, University of Pune) \\ ${ }^{2}($ *Department of Marine Biology, Karnataka University Post Graduate and Research Centre, Kodibag, \\ Karwar)
}

\begin{abstract}
Sex ratio of Ribbonfish, Lepturacanthus savala has been studied from Karwar waters, Uttar Kannada District Karnataka. Sex ratio indicates the proportion of males to females in a population. This is normally expected to be 1:1 in nature. Total 631 fish were studied during the period December 2011 to December 2012. Sex ratio was calculated for different months and size groups of the fish were tested by using Chi-square $\left(X^{2}\right)$ test. The ratio of males to females was found to be 1.7:0.5. The test of significance revealed that in January and February 2012 proportion of males and females varied significantly $\left(X^{2}=7.89, P<0.01\right.$ and $7.46, P<0.01)$ respectively. In other months the difference was significant and the chi-square test for pooled data did not show any significant variation $\left(X^{2}=2.28, P<0.05\right)$. The data on sex ratio in relation to size groups suggest that males outnumbered females in all the size groups. The chi-square test values for pooled data did not show much variation $\left(X^{2}=9.16, P<0.05\right)$ So far there have been some earlier reports about distribution, abundance and biological aspects but no attempt has been made towards the sex composition of Lepturacanthus savala, hence the present investigation was undertaken.
\end{abstract}

Keywords: Lepturacanthus savala, Ribbonfish, Sex ratio

\section{Introduction}

Karwar is one of the major fish landing centre situated at $14^{0} 50^{\prime} \mathrm{N}$ and $74^{0} 03^{\prime} \mathrm{E}$. Ribbonfish form a major fishery resource among the marine pelagic fin fishes of the Indian seas. The estimated annual marine fish catch during 2012 was 474, 981 tonnes $(21.7 \%)$. The total catch over the years has registered an increasing trend in Karnataka, of which Ribbonfish contributes about $6.2 \%$. Though various aspects of Lepturacanthus savala have been studied, no attempt has been made to study the sex ratio; hence present work has been carried out. The study on sex ratio gives an idea about sex viability, segregation and aggregation of sexes according to their feeding, breeding or migratory behaviour. Knowledge of the sex composition of catch also helps in understanding whether any differential fishing exists between males and females and if so, it's possible bearing on the fishable stock (Surendra and Neelakantan, 1983) [1]. According to Dutt, (1961) [2] females grow faster than males and also the variations are of marked nature exists between the ratio of sexes during different years and within the same year too. In which males showed predominance. Earlier Similar studies were made by Anantha et.al.(1995) [3],Sharma et.al.(1996) [4], Raje (2003) [5]. Such type of study may give some useful knowledge of sexual segregation and sex viability inherent to the stock besides yielding information and strength of spawning. Various authors made attempts to study sex ratio; the male-female ratio in the marine catfishes was studied by (Dan, 1977 [6]; Mojumdar, 1978) [7] and in the Yellow-stripe by (Tandon, 1962) [8]. Previously oil-Sardine investigation at Karwar was carried out by (Radhakrishnan, N.1969) [9]; similar attempts were made by (Prabhu, 1955 [10]; Nair, R. V., 1959 [11]; Antony Raja, B. T. 1963 [12], 1966 [13]; Ramanathan et. al. 1977 [14]). Hence the study of sex ratio of Lepturacanthus savala will contribute to the existing knowledge.

\section{Material And Methods}

Monthly random samples of Lepturacanthus savala were collected from Baithkol fish landing centre, Karwar $\left(14^{0}, 15^{\prime} \mathrm{N}\right.$ and $\left.74^{0} 03^{\prime} \mathrm{E}\right)$ from fishermen catches during the period December 2011 to December 2012. The collected fishes were brought to the laboratory and were properly cleaned, blotted and studied for the biological details. Length was measured to the nearest $\mathrm{mm}$. In the present study total 631 fish were examined.

All the fish were cut open and the sex was determined by examining the gonads. The sex ratio was calculated for different months and for specific length groups. The observed sex ratio of males to females was tested against natural ratio 1:1, by chi-square analysis (Snedecor, 1946) [15].

\section{Result And Discussion}

The data of sex ratio for each month (Table-1, Fig.1) showed that for all the months' number of males exceeded. In January, February and May the males outnumbered females. Similar observations were reported by 
Raju, (1962) [16], in Katsuwonus pelamis, he found that males are more than the females in 541-620 mm length sizes. Wade, (1950) [17], explained that the preponderance of males may be due to the aggressiveness of the males during spawning. In present investigation the ratio of males to females was found to be 1.7:0.5. Similar results were also reported by earlier workers. The flat fish Cynoglossus semifasciatus has a sex ratio of 1:1.3 (Seshappa and Bhimachar, 1955) [18], while in Cynoglossus macrostomas the two sexes showed a considerable degree of variation in their occurrence from month to month and year to year. Pooled data over a period of years shows that the ratio is 1:1.29 of males to females. In Cynoglossus dubius catches, the ratio was 1.4 males to 1 female where males were consistently more in number. But in larger size groups no males were found only females dominated the catch. During present study similar results were found in Lepturacanthus savala.

According to Talwar, (1964) [19] male and female fishes of the Malabar half beak, Hyporhamphus georgii congregate into separate schools while moving to the spawning grounds. There is a preponderance of males in the catches, the ratio of male to female being 1.80:1. Similar sexual segregation was observed even in the case of Australian garfish, Reprorhamphus melanochir, (Ling, 1958) [20].

In present study it is observed that in the months of January, February and May large number of males were found as compare to females, this may be because the male fish mature well in advance than female and may move to the spawning grounds so as to ensure maximum fertilization of the eggs - similar observations were made by Sarojini, (1957) [21] in Mugil parsia.

According to various investigations there seem to be seasonal fluctuations in the male-female ratio. In eels, though the average is 1:1.16 but in Muraenesox talabonoides the ratio was 1:0.62 during January, 1:4.89 in June and 1:2 during rest of the year in Bombay waters. There is no substantial evidence to show that there is any great segregation of the sexes in the overall landings (Mohamed, 1955) [22]. Similar observations were made in Lepturacanthus savala. For the month of January the Sex ratio was 1.13:0.88, in February it was 1.26:0.97 and in May 0.76:0.56. The significant change in the sex ratio with males predominating was found. Males were considerably in number than females, corresponding to the active spawning period of the Lepturacanthus savala.

In the size group wise ratio (Table-2, Fig.2), 250-300, 300-350, 350-400, 400-450, 450-500 the male as to female ratios were 1.7:0.6, 2.3:0.4, 1.8:0.5, 2.8:0.3, 3.7:0.3 respectively. In higher length sizes more number of females was recorded. According to Raju, (1962) [16] between the length sizes 541-620 mm. males were more than the females in Katsuwonus pelamis. As per available data, it is clear that sexes in marine fishes are not distributed uniformly with respect to sizes, season and region wise. Such dominance of a particular sex in the catches has been previously interpreted by Kesteven (1942) [23]. He found that in West Australian Waters, males of M. dobula predominated in the catches and he presumed that it was due to differential fishing. Sarojini (1957) [21] opinioned male and female fish congregate in separate schools while moving to the spawning grounds. Qasim, (1957) [24] suggested that the preponderance of one sex in a population is because of sexual difference in growth rate, the faster growth rate leads increasingly to the less loss from predator this influences the sex ratio.

\section{FIGURES AND TABLES}

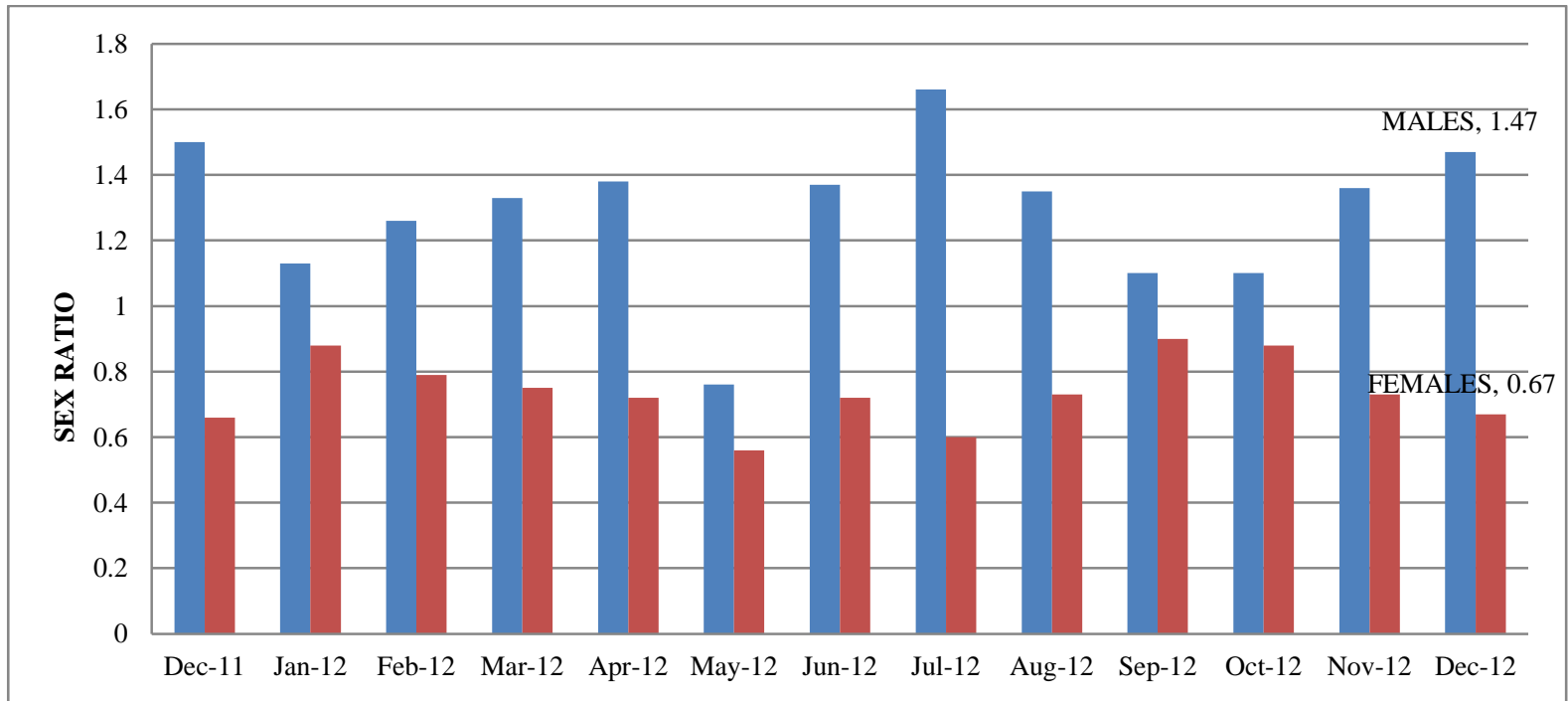

Fig. 1 Monthly variation in sex ratio of Lepturacanthus savala, during Dece- 2011 To Dece- 2012 
Sex ratio of Ribbonfish, Lepturacanthus savala (Cuvier, 1829) from Karwar waters, Karnataka

Table -1 Monthly Variation in Sex Ratio of Lepturacanthus savala During, Dece- 2011 To Dece- 2012

\begin{tabular}{|c|c|c|c|c|c|c|}
\hline MONTH & $\begin{array}{l}\text { TOTAL NO.0F } \\
\text { FISH }\end{array}$ & $\begin{array}{l}\text { NO. OF } \\
\text { MALES }\end{array}$ & $\begin{array}{l}\text { NO. OF } \\
\text { FEMALES }\end{array}$ & $\begin{array}{l}\text { SEX RATIO, } \\
\text { M:F }\end{array}$ & $\begin{array}{l}\text { EXPECTED NO. } \\
\mathrm{M}: \mathrm{F}\end{array}$ & $\begin{array}{l}\text { CHI } \\
\text { SQUARE }\end{array}$ \\
\hline Dec-11 & 50 & 30 & 20 & $1.50: 0.66$ & 25 & 2 \\
\hline Jan-12 & 67 & 45 & 22 & $1.13: 0.88$ & 33.5 & $7.89 * *$ \\
\hline Feb-12 & 59 & 40 & 19 & $1.26: 0.79$ & 29.5 & $7.46^{* *}$ \\
\hline Mar-12 & $48(13)$ & 20 & 15 & $1.33: 0.75$ & 17.5 & 0.71 \\
\hline Apr-12 & $47(16)$ & 18 & 13 & $1.38: 0.72$ & 15.5 & 0.8 \\
\hline May-12 & 58 & 37 & 21 & $0.76: 0.56$ & 29 & 4.4 \\
\hline Jun-12 & $29(10)$ & 11 & 8 & $1.37: 0.72$ & 9.5 & 0.48 \\
\hline Jul-12 & $27((03)$ & 15 & 9 & $1.66: 0.60$ & 12 & 1.5 \\
\hline Aug-12 & $46(06)$ & 23 & 17 & $1.35: 0.73$ & 20 & 0.9 \\
\hline Sep-12 & 42 & 22 & 20 & $1.10: 0.90$ & 21 & 0.08 \\
\hline Oct-12 & 49 & 26 & 23 & $1.10: 0.88$ & 24.5 & 0.18 \\
\hline Nov-12 & 52 & 30 & 22 & $1.36: 0.73$ & 26 & 1.22 \\
\hline \multirow[t]{2}{*}{ Dec-12 } & 57 & 34 & 23 & $1.47: 0.67$ & 28.5 & 2.12 \\
\hline & 631(48)\# & 351 & 232 & & & 29.74 \\
\hline
\end{tabular}

$* \mathrm{P}<0.01, * * \mathrm{P}<0.01, * * * \mathrm{P}<0.001 \quad$ CRITICAL VALU OF CHI SQUARE $=2.28=2.408,0.05,1, \mathrm{D}$. F. \# UNDETERMINED

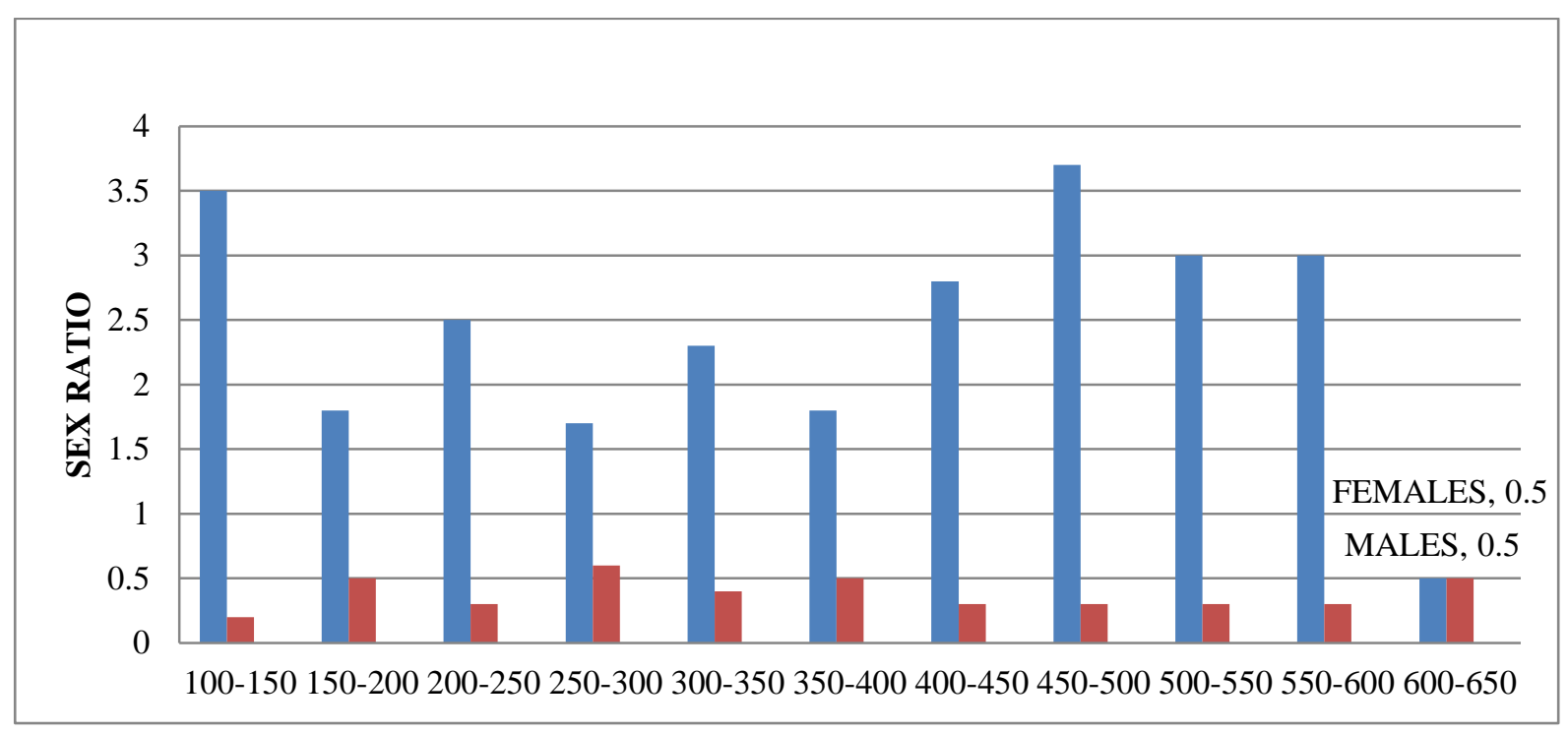

Fig.2- Variation in sex ratio of Lepturacanthus savala of different size groups

Table -2 Variation in Sex Ratio of Lepturacanthus savala of Different Size Groups

\begin{tabular}{|c|c|c|c|c|c|c|}
\hline $\begin{array}{c}\text { LENGTH } \\
\text { FREQ. }(\mathrm{mm})\end{array}$ & $\begin{array}{c}\text { TOTAL NO.0F } \\
\text { FISH }\end{array}$ & $\begin{array}{l}\text { NO. OF } \\
\text { MALES }\end{array}$ & $\begin{array}{c}\text { NO. OF } \\
\text { FEMALES }\end{array}$ & $\begin{array}{c}\text { SEX RATIO, } \\
\text { M:F }\end{array}$ & $\begin{array}{c}\text { EXPECTED NO. } \\
\text { M:F }\end{array}$ & $\begin{array}{c}\text { CHI } \\
\text { SQUARE }\end{array}$ \\
\hline $100-150$ & 9 & 7 & 2 & $3.5: 0.2$ & 4.5 & 2.7 \\
\hline $150-200$ & 17 & 11 & 6 & $1.8: 0.5$ & 8.5 & 1.47 \\
\hline $200-250$ & 81 & 58 & 23 & $2.5: 0.3$ & 40.5 & $15.12 * * *$ \\
\hline $250-300$ & 106 & 68 & 38 & $1.7: 0.6$ & 53 & $8.49 * *$ \\
\hline $300-350$ & 169 & 118 & 51 & $2.3: 0.4$ & 84.5 & $26.56 * * *$ \\
\hline $350-400$ & 115 & 74 & 41 & $1.8: 0.5$ & 57.5 & $9.46 * *$ \\
\hline $400-450$ & 58 & 43 & 15 & $2.8: 0.3$ & 29 & $13.51 * * *$ \\
\hline $450-500$ & 43 & 34 & 9 & $3.7: 0.3$ & 21.5 & $14.53 * * *$ \\
\hline $500-550$ & 12 & 9 & 3 & $3: 0.3$ & 6 & 3 \\
\hline $550-600$ & 20 & 15 & 5 & $3: 0.3$ & 10 & $5 *$ \\
\hline \multirow[t]{2}{*}{$600-650$} & 1 & 0 & 1 & $0.5: 0.5$ & 0.5 & 1 \\
\hline & 631 & 437 & 194 & & & 100.84 \\
\hline
\end{tabular}

$* \mathrm{P}<0.05, * * \mathrm{P}<0.01, * * * \mathrm{P}<0.001 \quad$ CRITICAL VALUE OF CHI SQUARES $=9.16=12.24,0.05,1, \mathrm{D} . \mathrm{F}$. 
The significant change in the sex ratio with males predominating was found. Males were considerably in number than females, corresponding to the active spawning period of the Lepturacanthus savala.

In the size group wise ratio (Table-2, Fig.2), 250-300, 300-350, 350-400, 400-450, 450-500 the male as to female ratios were 1.7:0.6, 2.3:0.4, 1.8:0.5, 2.8:0.3, 3.7:0.3 respectively. In higher length sizes more number of females was recorded. According to Raju, (1962) [16] between the length sizes 541-620 mm. males were more than the females in Katsuwonus pelamis. As per available data, it is clear that sexes in marine fishes are not distributed uniformly with respect to sizes, season and region wise. Such dominance of a particular sex in the catches has been previously interpreted by Kesteven (1942) [23]. He found that in West Australian Waters, males of M. dobula predominated in the catches and he presumed that it was due to differential fishing. Sarojini (1957) [21] opinioned male and female fish congregate in separate schools while moving to the spawning grounds. Qasim, (1957) [24] suggested that the preponderance of one sex in a population is because of sexual difference in growth rate, the faster growth rate leads increasingly to the less loss from predator this influences the sex ratio.

Thus the information on the sex ratio of Lepturacanthus savala will be helpful to exploit fishery resources on sustainable basis.

\section{Conclusion}

From the foregoing study it is obvious that our knowledge about various aspects of Lepturacanthus savala is considerable and it would be of interest. Among the Ribbon fish species Lepturacanthus savala is widely distributed and accounting for bulk of landings. This species was studied to fill up the gapes in our knowledge and will help to evolve suitable management policy. Regular monitoring of the Ribbon fish fishery should be undertaken.

\section{Acknowledgments}

The authors express gratitude to Dr. U. G. Bhat, and Dr. Kusuma Neelakantan, former chairmen's, Department of Marine Biology, K. U. P. G. Centre, Karwar, for their constant support and valuable guidance.

\section{References}

[1]. Surendra Babu and Neelakantan, Biology of Liza parsia in Kali estuary Karwar, Mahasagar. 16(3), 1983, 381-389.

[2]. Dutt, Biometric studies on Sardinella spp. of Waltair Coast. 1. Sardinella fimbriata (Val.) Proc. $1^{\text {st }}$ All India Congr. Zool., Pt. II, $1962,286$.

[3]. Anantha, C. S, P. Santha Joseph, G. V. S. Reddyand b. S. Raghunath, Reproductive biology of Gerris setifer (Hamilton-Buchanan) inhabiting the coastal waters of Mangalore. J. Aqua. Biology. 10 (1 \& 2), 1995, 61-65.

[4]. Sharma, S. V., Jayaraju, P. B. And Alankara Rao, T.J.S., Reproductive biology of tropical freshwater catfish, Mystus cavasius (Siluriformes: Bagridae) from Guntur, India. J. Aqua.biology.11 (1\&2), 1996, 33-40.

[5]. Raje, S. G, On the biology of Tachysurus caelatus (VAL.) from Veraval. J. Ind. Fish. Asson. 30, 2003, 91-96.

[6]. Dan S.S., Intra-ovarian studies and fecundity in Nemipterus japonicus (Bloch). Indian J.Fish. 24 (1 \& 2), 1977, $48-55$.

[7]. Mojumdar, P., Maturity and spawning of the catfish, Tachysurus thalassinus (Ruppel), off Waltair coast. Indian J. Fish 25(1 \& 2), 1978, 109-121.

[8]. Tandon,K. K., Biology and Fishery of Choo Parai, Selaroides leptolepis (Cuv. \& Val.). Indian J. Fish., 8 (1), 1962, 127-144.

[9]. Radhakrishnan, N., Oil sardine investigations at Karwar. Indian J. Fish 12 a (1), 1969, 99-117.

[10]. Prabhu, Some aspects of the biology of the ribbon-fish, Trichurus haumela (Forskal). Indian J. Fish 3(1), 1955, 132-163.

[11]. Nair, R. V., Notes on the spawning habits and early life-history of the oil-sardine, Sardinella longiceps (Cur. And Val.) Indian J. Fish 6, 1959, 342

[12]. Antony Raja, B. T., An instance of hermaphroditism in the Indian oil sardine, Sardinella longiceps (Cuv. And Val.). J. Mar. Biol. Ass. India. Vol. V, no.1, 1963, 148-150.

[13]. Antony Raja, B. T., On the maturity stages of the Indian oil-sardine, Sardinella longiceps (Val.) with note on incidence of atretic follicles in advanced ovaries. Indian J. Fish., 13 (1\&2), 1966, 27-47.

[14]. Ramanathan, N., Vijaya, P., Ramaiyan, V and Natarajan, R., On the biology of the large-scaled tongue sole. Cyanoglossus macrolepidotus (Bleeker). Indian J. Fish 24(1\&2), 1977, 83-89.

[15]. Snedecor, G. W, Statistical methods. Iowa State College Press, Ames, Iowa, 1946, 485.

[16]. Raju, Studies on the spawning of the oceanic Skipjack, Katsuwonus pelamis (Linnaeus) in Minicoy waters. Proc. Symp. In Scombroid Fishes, Symposium Series I. Mar. Biol. Ass. India Part II, 1962, 744-768.

[17]. Wade, C. B, Observations on the spawning of Philippine tuna. Fish. Bull. U. S. 51, 1950, 407-423.

[18]. Seshappa, G. and Bhimachar, B. S, Studies on the fishery and biology of the Malabar sole Cyanoglossus semifasciatus (Day). Indian J. Fish., 2, 1955, 180-230.

[19]. Talwar, P. K., (1964). A contribution to the Biology of the halfbeak, Hyporhamphus georgii (Cuv. \& Val.) (Hemirhamphidae).Indian J. Fish. 9(1): 168-196.

[20]. *Ling, (1958). The sea garfish, Reprorhamphus melanochir (C. V.) (Hemiramphidae) in South Australia: breeding, age determination and growth rate. Aust. J. Mar. Freshw. Res. 9(1):60-110.

[21]. Sarojini, K.K. (1957). Biology and fisheries of the grey mullets of Bengal. Biology of Mugil parsia (Hamilton) Indian j. Fish. 4:160-207.

[22]. *Mohamed K. H., (1955). "A study on marine eels in Bombay", M. Sc. Thesis, University of Bombay.

[23]. Kesteven, G. L., Studies on the biology of Australian mullet. Part 1. Account of the fishery and the preliminary statement of the biology of M dobula Gunther., Coun. Sci. Indutr. Res. Bull, Melbourne, 1942, 157.

[24]. Qasim, (1957), The biology of Blennius pholis (L.) (Teleostei). Proc. Zool. Soc. Lond., 128: 161-208 